Jacek Puchalski

Warszawa

\title{
Refleksje nad źródłami do dziejów bibliotek w amerykańskiej literaturze przedmiotu z perspektywy badań nad źródłami do historii książnic w Polsce w pierwszej połowie XX w.
}

Badania bibliologiczne mają charakter interdyscyplinarny ${ }^{1}$ i w dużym stopniu porównawczy ${ }^{2}$. Według Barbary Bieńkowskiej „służą nie tylko własnej dyscyplinie, lecz także innym dziedzinom nauk, zwłaszcza humanistycznych i spolecznych [...] muszą stanowić istotny komponent nauki o kulturze i społeczeństwie" , a także o komunikacji, literaturze, psychologii, socjologii i pedagogice, a przede wszystkim są integralną częścią wiedzy historycznej, historii literatury, sztuki i kultury ${ }^{4}$. Za B. Bieńkowską należy również podkreślić, że: „Książka, jako nośnik treści, kanał wędrówki idei, środek oddziaływania, zajmuje również ideologów i polityków wszystkich czasów i orientacji”.5.

Z multidyscyplinarnego i uniwersalnego znaczenia badań i metod bibliologicznych, a równocześnie $z$ faktu jednak nieznacznego wykorzystywania dorobku bibliologii w świecie nauki, wynika konieczność dalszych prac o charakterze metodologicznym, w tym także źródłoznawczych. Zwłaszcza, że źródła bibliologiczne coraz częściej staja się przedmiotem badań specjalistów reprezentujących inne dziedziny niż bibliologia 6

\footnotetext{
${ }^{1}$ Jest to dominujący pogląd w światowym księgoznawstwie od lat osiemdziesiątych XX w., zob. m.in. artykuły - w materiałach konferencyjnych: Histoires du livre: Nouvelles orientations: Actes du Colloque du 6 et 7 septembre 1990 Göttingen, ed. H. E. Bödeker, Paris 1995 - takich autorów, jak: F. Barbier, Le comparatisme comme nécessité heuristique pour l'historien du livre et de la culture, s. 433-49; R. Darnton, Histoire du livre. Geschichte des Buchwesens, An Agenda for Comparative History, s. 451-58; J. L. Flood, Überlegungen zu Buch- und Buchgeschichte aus komparatistischer und interdisziplinärer Sicht, s. 385-416; H.-J. Martin, Pour une histoire comparative du livre: quelques points de vue, s. 417-32.

${ }^{2}$ J. Pirożyński, Nowe kierunki w zagranicznych badaniach nad dawnq książka, „Historyka”, 1996, t. 26 , s. $71-87$.

${ }^{3}$ B. Bieńkowska, Zastosowania i konteksty wiedzy o książce, w: Wiedza o książce w nauce $i$ dydaktyce. Konferencja Warszawa 16-17 listopada 1994, red. M. Kisilowska, J. Puchalski, D. Kuźmina, Warszawa 2000, s. 56; K. Migoń, Kultura ksiązki. Program dla bibliologii i potrzeba dla studiów bibliotekoznawczych, w: Nauka o książce, bibliotece i informacji we współczesnym świecie, red. merytor. M. Banacka, Warszawa 2003, s. 12.

${ }^{4}$ Zob. m.in.: K. Migoń, Bibliologia - nauka o kulturze książki, „Nauka”, 2005, [nr] 2, s. 49-57.

${ }^{5}$ B. Bieńkowska, Zastosowania i konteksty wiedzy o książce..., s. 56.

${ }^{6}$ Tamże, s. 64.
} 
Badania nad historią bibliotek są jednym $z$ najważniejszych elementów bibliologii i mają już długą tradycję̧. Krzysztof Migoń zaliczył je do dziewięciu zasadniczych kwestii określających „oblicze historiografii książki”. Wedle części badaczy historia bibliotek stanowi integralny problem bibliotekoznawstwa jako odrębnej dyscypliny naukowej'. Spory metodologiczne nie dotyczą samego znaczenia ksiażnic, jako ważnych ośrodków życia kulturalnego i intelektualnego ${ }^{10}$, którym według Zofii Gacy-Dąbrowskiej „przypada rola gromadzenia i ochrony przed rozproszeniem piśmienniczych wytworów kultury wszystkich czasów jako wartości poznawczych, moralnych i estetycznych oraz udostępnianie tych wytworów współczesnym i przyszłym pokoleniom dla zachowania ciągłości wytwarzanych dóbr i możliwości wykorzystywania osiągniętych już wyników myśli ludzkiej. Jest to ich rola fundamentalna i pierwotna. W zależności od typu zadania bibliotek różnicują się." ${ }^{11}$. W piśmiennictwie naukowym podkreśla się interdyscyplinarne znaczenie historiografii bibliotek. Śladem księgoznawców francuskich wielu uczonych zwraca uwagę na związki badań nad dziejami książnic $z$ lokalną i regionalną historią społeczną i historią kultury ${ }^{12}$. Mo-

\footnotetext{
${ }^{7}$ Biblioteka, jako element procesu bibliologicznego, nadal pozostaje przedmiotem zainteresowania teoretyków bibliologii, zob. m.in. R. Estivals, Schemas pour la bibliologie, Viry-Chatillon 1976; idem, Histoire du livre et bibliologie, „Leipziger Jahrbuch zur Buchgeschichte”, 1994, nr 4, s. 18-19.

${ }^{8}$ „1. przedmiot historii książki; historia formy i historia funkcji ksiazzki; 2. metody badawcze; 3 . podstawa źródłowa; 4. periodyzacja dziejów książki; 5. zakres terytorialny; europocentryczna i uniwersalna historia książki; 6 . historia różnych typów książek i poszczególnych książek; 7. ogólna historia książki wobec historii poszczególnych zagadnień księgoznawczych; historia książki a historia bibliotek; 8. historia czytelnictwa wobec historii książki; 9. potrzeba historiografii książki dla innych dyscyplin księgoznawczych i dla innych nauk". Zob. K. Migoń, Uwagi o rozwoju i perspektywach historiografii ksiażki, „Studia o Książce”, 1975, t. 5, s. 16.

${ }^{9}$ Metodologia bibliotekoznawstwa i informacji naukowej, red. S. Kubiak, Poznań 1976; Z historycznych i metodologicznych problemów badań księgoznawczych i bibliotekoznawczych, red. Z. Jabłoński, Kraków 1985; J. Ratajewski, Wprowadzenie do bibliotekoznawstwa, czyli wiedza o bibliotece w różnych dawkach. Do druku przygot. Z. Żmigrodzki przy współpr. E. Gondek, Warszawa 2002; oraz: J. Kołodziejska, Metodologia badań w zakresie bibliotekoznawstwa. „Bibliotekarz”, 1975, nr 11/12, s. 263-270; Z. Gaca-Dąbrowska, O teoretycznych problemach nauki o bibliotece. „Studia o Książce”, 1980, t. 10, s. 201-210; J. Krochmalska, Przeglad publikacji na temat metod badań stosowanych w nauce o ksiażce, bibliotece i informacji naukowej (w kontekście ostatniej książki Jerzego Ratajewskiego), w: W kręgu ksiązki, biblioteki i informacji naukowej, Katowice 2004, s. 95-116. Zob. także rubrykę Krystyny Bednarskiej-Ruszajowej $Z$ teorii i metodologii ksiegarstwa $i$ dyscyplin pokrewnych publikowaną od $1984 \mathrm{r}$. (t. 14) do 1993 r. (t. 19) w „Studiach o Książce” - autorka omawiała na jej łamach publikacje poświęcone teorii i metodologii księgoznawstwa, bibliotekoznawstwa i informacji naukowej.

${ }^{10}$ P. Raabe, Library history and the History of Books: Two Fields of Research for Librarians, ,Journal of Library History" 1984, 19, nr 2, s. 284.

${ }^{11}$ Z. Gaca-Dąbrowska, Biblioteki i ich rola w rozwoju życia naukowego w Polsce (1919-1951), w: Historia nauki polskiej, red. B. Suchodolski, t. 5: 1918-1951, cz. 1, Wrocław 1992, s. 569.

${ }^{12}$ Powiązanie historii bibliotek $z$ dziejami życia intelektualnego, kulturalnego, społecznego i politycznego poszczególnych krajów czy regionów jest dominująca tendencją także w opracowaniach badaczy nie wywodzących się z Europy czy USA, zob. np. R. K. Bhatt, History and Development of Libraries in India, New Delhi 1995; V. S. Hernandez, History of Book and Libraries in the Philippines, 1521-1900, Manila 1996.
} 
żna tutaj wymienić na przykład autorów angloamerykańskich ${ }^{13}$, takich jak m.in. Kenneth E. Carpenter $z$ Uniwersytetu Harvarda, zajmujący się historią bibliotek $z$ punktu widzenia ich roli w życiu intelektualnym, kulturalnym, społecznym i politycznym Ameryki ${ }^{14}$; Wayn A. Wiegand i Donald G. Davis Jr. wydawcy Encyclopedia of Library History ${ }^{15}$; Donald F. McKenzie $z$ Oxfordu, David J. Kitterick $z$ Cambridge i Ian R. Wilson $z$ Londynu, wydawcy The Cambridge History of the Book in Britain ${ }^{16}$, siedmiotomowego dzieła poświęconego dziejom angielskich bibliotek od czasów najdawniejszych po najnowsze oraz księgoznawców niemieckich ${ }^{17}$ na czele ze środowiskiem mogunckim (Institut für Buchwissenschaft der Johannes Gutenberg-Universität Mainz ${ }^{18}$ i międzynarodowym gronem badaczy skupionym wokół Biblioteki Księcia Augusta w Wolfenbüttel (Wolfenbütteler Arbeitskreis für Bibliotheks-, Buch und Mediengeschichte; publikującym ważne czasopismo poświęcone historii książki i bibliotek „Wolfenbüitteler Notizen zur Buchgeschichte” oraz serię Wolfenbütteler Schriften zur Geschich-

${ }^{13}$ Libraries and Culture. Proceedings of Library History Seminar VI, 19-22 March 1980, Austin, Texas, ed. By D. G. Davis, Austin 1981; R. Krzys, G. Litton, World Librarianship: a Comparative Study, New York, Basel 1983, s. 6-10; W. A. Wiegand, History of Libraries, w: International Encyclopedia of Information and Library Science, second ed. by J. Feather, P. Sturges, London 2003, s. 225-226; P. Hoare, Library History, w: British Librarianship and Information Work, t. 1: 1981-85, ed. D. W. Bromley, A. M, Allott, London 1987, s. 284-293; P. Sturges, Library History, w: British Librarianship and Information Work 1986-90, Vol. 1: General Libraries and the Profession, ed. D. W. Bromley, A. M. Allott, London 1992, s. 236-241; A History of Libraries in Britain and Ireland, ed. by A. Black, Cambridge 2006.

${ }^{14}$ K. E. Carpenter, Readers and Libraries. Toward a History of Libraries and Culture in America, Washington 1996.

${ }^{15}$ New York 1994.

${ }^{16}$ Do końca 2005 r. ukazały się dwa tomy: 3: 1400-1557, ed. by L. Hellinga, J. B. Trapp, Cambridge 1999; oraz 4: 1557-1695, ed. by J. Barnard, D. F. McKenzie, assisted by M. Bell, Cambridge 2002. Fragment czwartego tomu został opublikowany w Internecie, zob. [dokument elektroniczny] http://assets.cambridge.org/052166/182X/sample/052166182Xws.pdf.

${ }^{17}$ Np. P. Karstedt, Studien zur Soziologie der Bibliothek, 2. Aufl., Wiesbaden 1965; Bibliotheksgeschichte als wissenschaftliche Disziplin: Beiträge zur Theorie und Praxis, ed. P. Vodosek, Hamburg 1980; Die Erforschung der Buch und Bibliotheksgeschichte in Deutschland: Paul Raabe zum 60. Geburtstag gewidmet, hrsg. v W. Arnold, W. Dittrich, B. Zeller, Wiesbaden 1987; Beiträge zur Bibliothekstheorie und Bibliotheksgeschichte - Contributions to Library Theory and Library History, hrsg. v. P. Kaegbein, P. Vodosek und P. Zahn, München-London-New York-Paris 1994; P. Zahn, Bibliothek Kultur - Information. Beiträge eines internationalen Kongresses anläslich des 50 jährigen Bestehens der Fachhochschule für Bibliothekswesen, Stuttgart vom 20. Bis 22. Oktober 1992, hrsg. v. P. Vodosek in Zusammenarbeit mit A. Blum, Stuttgart 1993; P. Vodosek, Bibliotheksgeschichte in Deutschland, w: Bibliotheken in der literarischen Darstellung = Libraries in Literature, hrsg. P. Vodosek, G. Jefcoate, Wiesbaden 1999, s. 11-22.

${ }^{18}$ S. Füssel, Buchwissenschaft als Kulturwissenschaft, w: Im Zentrum: das Buch. 50 Jahre Buchwissenschaft in Mainz, hrsg. von S. Füssel, Mainz 1997, s. 62-73. 
te des Buchwesens $)^{19}$. Spośród opracowań niemieckich historyków bibliotek czasów najnowszych warto zwrócić uwagę na Deutsche Bibliotheksgeschichte der neuesten Zeit (1800-1945) Ladislausa Buzasa. Autor podkreślając, że historia bibliotek jest częścią historii czasów, w których działały, zwracając uwagę na jej interdyscyplinarne znaczenie, kładł nacisk na konieczność oparcia badań nad dziejami książnic na tradycyjnej metodologii historii ${ }^{20}$.

Znamienne dla ewolucji historii bibliotek jest to, że jedno $z$ dwóch najważniejszych czasopism dziedzinowych - amerykański ,Journal of Library History”, wydawany od 1966 r. - w 1988 r. zmieniło nazwę na „Libraries \& Culture” skupiając się na historii bibliotek właśnie w kontekście historii kultury i historii społecznej ${ }^{21}$. Podobny profil, rozszerzony o związki historiografii bibliotek $z$ historią nauki, cechuje kolejne, wiodące czasopismo dziedzinowe, brytyjskie „Library History ${ }^{\prime 22}$ wydawane przez The Library and Information History Group (LIHG) ${ }^{23}$, działającą od 1962 r. przy Chartered Institute for Library and Information Professional's (CILIP) ${ }^{24}$.

Niejako podsumowanie ewolucji historiografii bibliotek stanowi artykuł Jean-Pierre V. M. Hérubela Historiography's Horizon and Imperative: Febvrian Annales Legacy and Library History as Cultural History „opublikowany w Libraries \& Culture”25. Autor, nawiązując do francuskiej szkoły historiograficznej „Annales"26, promującej badania interdyscyplinarne, tj. konieczność stosowania przez historyków metod $z$ zakresu etnologii, ekonomii, psychologii, geografii, demografii i socjologii, przy zachowaniu prymatu historii wobec innych dyscyplin ${ }^{27}$, rozpatruje historię bibliotek w kontekście antropologii historycznej, stworzonej przez tak wybitnych historyków jak: Marc Bloch, Lucien Febvre ${ }^{28}$, Jacques Le Goff, Michel Foucault, Johan Huizinga i Aron Guriewicz, głoszących m.in., że

${ }^{19} \mathrm{Z}$ innych czasopism niemieckich, poświęcających dużo uwagi problematyce historii bibliotek, należy przede wszystkim wymienić: „Zeitschrift für Bibliothekswesen und Bibliographie”, zob. [dokument elektroniczny] http://www.klostermann.de/zeitsch/zfbb_hmp.htm oraz „Bibliothek. Forschung und Praxis”, wydawane od 1999 r. przez Niedersächsische Staats- und Universitätsbibliothek Göttingen, zob. [dokument elektroniczny] http://www.bibliothek-saur.de/. Na temat niemieckiej historiografii bibliotek zob. też: P. Kaegbein, Two Centers of German Research Activities in Library History: Cologne and Wolfenbüttel, „Journal of Library History”, 1986, 21, nr 2, s. 456-473; P. Vodosek, Library History in Germany: a Progress Report, „Library History” 2001, 17, s. 119-126.

${ }^{20}$ L. Buzas, Deutsche Bibliotheksgeschichte der neuesten Zeit (1800-1945), Wiesbaden 1978.

${ }^{21}$ Kwartalnik publikowany przez Szkołę Informacji Uniwersytetu Teksańskiego w Austin, zob. [dokument elektroniczny] http://www.gslis.utexas.edu/ landc/.

22 [Dokument elektroniczny] http://www.cilip.org.uk/groups/lhg/journal.html.

${ }^{23}$ [Dokument elektroniczny] http://www.cilip.org.uk/groups/lhg/welcome.html.

${ }^{24}$ [Dokument elektroniczny] http://www.cilip.org.uk/default.cilip.

${ }^{25} 200439$ nr 3 s. 293-312.

${ }^{26}$ Szkoła „Annales” wywodzi swą nazwę od tytułu pisma „Annales d’Histoire Economique et Sociale”, wydawanego od 1929 r. przez M. Blocha i L. Febvre`a.

${ }^{27}$ B. Geremek, W. Kula, Przedmowa, w: F. Braudel, Historia i trwanie, Warszawa 1999, s. 5-6.

${ }^{28}$ M.in. autor rozprawy L 'apparition du livre, Paris 1958 (drugie wydanie 1970) napisanej wespół z bibliologiem H.-J. Martinem. Zob. też: Książka, ten zaczyn, przeł. A. Mencwel, „Przegląd Humanistyczny”, 1989 , nr 8/9, s. 163-190. 
historia jest społeczną historią kultury - całością złożoną ze zjawisk ekonomicznych, kultury materialnej, życia codziennego, a także $z$ wierzeń, ideologii, obyczajów i rytuałów ${ }^{29}$. Szkoła „Annales”, do której nawiązali Henri-Jean Martin i Roger Chartier ${ }^{30}$, ukształtowała francuską koncepcję bibliologii. Jej dominującą cechą jest zwrot, zakładający wykorzystanie masowych źródeł archiwalnych, ku badaniom socjologicznym nad rozpowszechnianiem i społeczną recepcją książki ${ }^{31}$, a w tym kontekście nad historią bibliotek ${ }^{32}$.

Zgodnie $z$ wymaganiami nowoczesnej teorii bibliologii - założenia szkoły francuskiej rozpowszechniły się nie tylko w omówionym wyżej piśmiennictwie bibliologicznym krajów anglojęzycznych i niemieckojęzycznych, ale także m.in. w Hiszpanii, Rosji i Włoszech - do koncepcji „społeczno-kulturalnego” wymiaru historii bibliotek nawiązuje także polska, współczesna historiografia bibliotek.

Historia książnic - Jadwiga Kołodziejska pisze o historyczno-kulturowej analizie społecznej roli bibliotek w różnych okresach rozwoju społeczno-kulturalnego Polski ${ }^{33}$ - obejmuje m.in. badania nad rozwojem poszczególnych bibliotek bądź ich typów, badania nad działalnością książnic jako instytucji, ich strukturami organizacyjnymi, procesami bibliotecznymi (gromadzenie, przechowywanie, opracowywanie i użytkowania zbiorów), księgozbiorami, a także badania nad współpracą międzybiblioteczną, wyposażeniem i budownictwem bibliotecznym, wreszcie czytelnictwem książki oraz badania nad funkcją bibliotek w społeczeństwie, kulturze, oświacie i nauce. Jak podkreśla Z. Gaca-Dąbrowska, historia bibliotek stanowi punkt wyjścia do formułowania problematyki badawczej historii bibliotekarstwa, gdyż „bez poznania rozwoju ogólnych form działalności bibliotecznej, zawodu bibliotekarza i jego warsztatu oraz narzędzi, jakimi się on posługiwał, a także samej nauki, która formułowała zasady bibliotekarskiej pracy - nie można dostatecznie zrozumieć i ocenić historii bibliotek”34.

Na podobne związki zwraca uwagę m.in. Henryk Hollender w artykule „Wiedza o książce w praktyce bibliotecznej”35. Odnosząc się do współczesnego bib-

${ }^{29}$ W. Wrzosek, Historia - Kultura - Metafora. Powstanie nieklasycznej historiografii, Wrocław 1995.

${ }^{30}$ M.in. wydawca: Histoires de la lecture, un bilans des recherches, Paris 1995.

${ }^{31}$ H.-J. Martin, Histoire du livre et bibliologie, w: Encyclopédie internationale de bibliologie. Les sciences de l'ecrit, sous la direction de R. Estivals, avec collab. de J. Meyriat, F. Richaudeau, Paris 1993, 287-313; zob. tė̇: Dictionnaire encyclopédique du livre, sous la direction de P. Fouché, D. Péchoin, P. Schuwer et la responsabilité scientifique de P. Fouché, J.-D. Mellot, A. Nave [et al.], préface de H.-J. Martin, Paris 2002.

${ }^{32}$ Zob. m.in.: Histoire des bibliothèques françaises, t. 4: Les bibliothèques au XXe siècle, 1914-1989, dir. C. Jolly, Paris 1992; G. K. Barnett, Histoire des bibliotheques publiques en France de la Révolution à 1939, Paris 1987. Zob. też omówienia francuskiego piśmiennictwa $z$ ostatniego trzydziestolecia XX w. i początku XXI w. poświęconego historii bibliotek: H.-J. Martin, Geschichte des Buchwesens aus französischer Sicht. Geschichte und Perspektiven, „Leipziger Jahrbuch zur Buchgeschichte” 1991, nr 1, s. 23-51; D. Varry, L'histoire des bibliotheques en France, „Bulletin des bibliotheques de France”, 2005, 50, nr 2, s. $16-22$.

${ }^{33}$ J. Kołodziejska, Kultura. Gospodarka. Biblioteki, Warszawa 1992.

${ }^{34}$ Z. Gaca-Dąbrowska, Sytuacja $w$ badaniach nad dziejami bibliotek i bibliotekarstwa $w$ XIX $i$ XX $w$., „Studia o Książce” 1982, t. 12, s. 67.

${ }^{35}$ H. Hollender, Wiedza o książce $w$ praktyce bibliotecznej, w: Wiedza o książce w nauce $i$ dydaktyce..., s. 70-80. 
liotekarstwa stwierdził, że to przecież kompetencje bibliotekarzy decydują o funkcjonowaniu biblioteki, a w przypadku historii bibliotek to bibliotekarze decydują w duże mierze o wartości źródeł do ich dziejów ${ }^{36}$. Bibliotekarz zatem w naturalny sposób tworzy warsztat dla badań historyka bibliotek i powinien mieć nie tylko tego świadomość, ale i odpowiednie kompetencje. Owe kompetencje to wg H. Hollendra m.in. znajomość materialnych aspektów książki i jej produkcji, która pozwala na umiejętne przechowywanie i ochronę zbiorów, znajomość metody bibliograficznej, która jest niezbędna przy opracowaniu zbiorów i tworzeniu bibliotecznego aparatu informacyjno-wyszukiwawczego, znajomość problematyki czytelnictwa, potrzeb użytkowników bibliotek i ich kompetencji czytelniczych, która wpływa (lub nie - zależnie od poziomu kompetencji bibliotekarzy) na organizację gromadzenia zbiorów i ich udostępniania, a także współpracę międzybiblioteczną̧

O poziomie kompetencji bibliotekarzy decyduje także znajomość historii bibliotek. Jak zaznacza H. Hollender nie chodzi o „encyklopedyczną historię bibliotek”, o „biografie książnic”, ale o organizację pracy w bibliotekach, „kształtowanie się ich systemu dostępu, zasady doboru materiałów, rozmaicie pojmowane zadania i funkcje bibliotek, różne sposoby kształtowania ich wnętrz i gmachów, sposoby zarządzania, kultury organizacji”38.

Klasycznie natomiast ujmuje historiografię bibliotek Karl-Heinz Weimann, wiążąc jej rozwój $z$ ewolucją historii jako dyscypliny naukowej, uwzględniając przy tym związek między treścią opracowań $z$ zakresu dziejów bibliotek, a poziomem i stanem bibliotekarstwa będącego przedmiotem zainteresowania historyków książnic ${ }^{39}$.

$Z$ powyżej cytowanych wypowiedzi, zarówno odnoszących się do poznawczego znaczenia badań nad historią bibliotek, jak i podkreślających ich praktyczną rolę dla bibliotekarstwa, wynika konieczność rozwijania refleksji nad charakterem i metodologią badań w zakresie historii bibliotek, nad specyfiką problematyki źródłoznawczej w tej dziedzinie, w tym nad typologią źródeł, kwestią ich krytyki i wykorzystania ${ }^{40}$.

\footnotetext{
${ }^{36}$ Tamże, s. 77.

${ }^{37}$ H. Hollender, Wiedza o książce..., s. 73-74.

${ }^{38}$ Tamże, s. 74.

${ }^{39}$ K. H. Weimann, Bibliotheksgeschichte. Lehrbuch zur Entwicklung und Topographie des Bibliothekswesen, München 1975.

${ }^{40}$ Zob. m.in.: J. A. Passet, Historiography of Library History, w: Encyclopedia of Library History, ed. by W. A. Wiegand, D. G. Davis Jr, New York 1994, s. 260-262.
} 


\section{Wybrane typologie źródeł do historii bibliotek w amerykańskiej litera- turze przedmiotu $z$ perspektywy badań nad źródłami do historii książnic w Polsce w pierwszej połowie XX w.}

Od lat pięćdziesiątych XX w. tradycyjna historia bibliotek, rozumiana jako historia instytucji ${ }^{41}$, rozwinęła się $\mathrm{w}$ kierunku interdyscyplinarnych, porównawczych badań nad społeczną rolą bibliotek w różnych okresach życia społeczno-kulturalnego poszczególnych krajów. Kształtowaniu się przedmiotu badań historiografii bibliotek, wzrostowi ilości, zróżnicowanych tematycznie i pod względem poziomu naukowego, publikacji poświęconych dziejom poszczególnych książnic, typów bibliotek i działalności bibliotecznej na określonych terenach towarzyszyły m.in. edycje źródeł, publikacje bibliografii i przewodników po źródłach do historii bibliotek oraz refleksja teoretyczna zmierzająca do określenia zasad naukowego wykorzystania źródeł. Zgadzano się zazwyczaj, że podstawą badań nad źródłami winna być metodologia źródłoznawstwa historycznego, przy czym część autorów postulowała konieczność uwzględnienia specyfiki źródeł do dziejów bibliotek, inni owej specyfiki nie dostrzegali ${ }^{42}$.

W latach siedemdziesiątych XX w. nastapił rozwój amerykańskich badań nad źródłami do dziejów bibliotek. Ich wyniki są prezentowane w cyklicznych

${ }^{41}$ Zwolennikiem takiego, instytucjonalnego, ujęcia historii bibliotek był m.in. Ferdinand Eichler, autor rozprawy: Quellensammlung zur Geschichte des deutschen Bibliothekswesens, „Zentralblatt für Bibliothekswesen”, 1903, 20, s. 224-225. Określając zasób źródłowy do historii książnic niemieckich wziął pod uwagę tylko źródła pisane: katalogi biblioteczne, informacje o książkach znajdujące się w posiadaniu osób prywatnych, informacje o darowiznach, zakupie książek, rachunki umożliwiające identyfikację książek, wydatki na cele biblioteczne, inskrypcje na banknotach, na budynkach, akta osobowe bibliotekarzy oraz informacje o udostępnianiu zbiorów bibliotecznych. Według F. Eichlera źródłem do historii bibliotek może być każde, pisane świadectwo, potwierdzające istnienie kolekcji książek. Autor nie sklasyfikował wyróżnionych przez siebie źródeł, pominął równiė̇ źródła niepisane.

${ }^{42}$ Interesującą typologię źródeł do historii bibliotek zaproponował w połowie lat pięćdziesiątych południowoafrykański uczony Herman Jean de Vleeschauwer, wydawca czasopisma „Mousaion”. Podzielił źródła na:

- materiał archeologiczny,

- napisy (epigramaty),

- źródła pisane: sprawozdania $z$ podróży, annały, anegdoty, dokumenty urzędowe (np. reguły zakonne, statuty uniwersyteckie, korespondencje), katalogi, bibliografie, rozprawy o organizacji bibliotek, literatura fachowa,

- budynki, pomieszczenia i wyposażenie bibliotek.

H. J. Vleeschauwer stwierdził, że każda dyscyplina naukowa posiada własny, ograniczony zasób źródeł, który stanowi dla niej bazowy materiał badawczy. Równocześnie podkreślił, że historia bibliotek nie posiada takiego zbioru własnych, specyficznych źródeł za wyjątkiem części pomieszczeń w budynkach bibliotecznych przystosowanych wyłącznie do działalności bibliotecznej. Pominął w ten sposób kilka ważnych grup źródeł, przede wszystkim zbiory biblioteczne lub ich fragmenty, bądź pojedyncze egzemplarze, oraz źródła ikonograficzne. Takie stanowisko wynikało $z$ poglądu H. J. Vleeschauwera, że biblioteki nie mogą być traktowane jako izolowany, samoistny fenomen, bowiem nie jest istotne jak wysoko ceni się ich kulturalną rolę - są i pozostają jedynie instytucją pomocniczą w rozpowszechnianiu książki, elementem procesu bibliologicznego. Zob. H. J. Vleeschauwer, Library History in Library Science, „Mousaion”, 1958, nr 29-30, s. 16. 
przeglądach na łamach „Libraries \& Culture” (wcześniej „Journal of Library History") ",43, a także w opracowaniach, i wydawnictwach informacyjnych ${ }^{44}$. Poglądy amerykańskich badaczy na problemy związane ze źródłami do dziejów książnic przedstawię na przykładzie rozważań Haynesa McMullena, Leonarda J. Batesa i Rycharda Krzysa, bowiem wydają się one w dużym stopniu reprezentatywne dla amerykańskiej historiografii bibliotek.

H. McMullen w artykule Primary sources in library research ${ }^{45}$, opublikowanym w 1970 r., sklasyfikował źródła według częstotliwości ich występowania i wiarygodności, dzieląc je na prymarne, pierwotne (primary sources) - tj. źródła będące bezpośrednim, oryginalnym świadectwem obserwacji zarejestrowanej naocznie lub za pomocą innych zmysłów, względnie przy pomocy urządzeń mechanicznych np. magnetofonów - i wtórne (secondary sources). W grupie źródeł prymarnych H. McMullen wyodrębnił materiały, których prymarność może być dyskusyjna, a zatem i wiarygodność wątpliwa, określając je jako primariness. Zaliczył do nich:

1. pisane relacje bibliotekarzy ze zdarzeń, których mogliby być naocznymi świadkami, ale nie stwierdzają tego jednoznacznie;

2. informacje źródłowe na temat ogólnych trendów dominujących w bibliotekarstwie zawarte w źródłach pisanych, co do których istnieje duże prawdopodobieństwo, że pochodzą $z$ tzw. „drugiej ręki”;

3. biblioteczne zestawienia statystyczne, zawierające dane zebrane przez samego autora zestawienia jak i skompilowane $z$ innych źródeł ${ }^{46}$.

Konieczność wyodrębnienia „primariness” świadczy o zawodności podziału zastosowanego przez H. McMullena, zresztą często używanego w piśmiennictwie amerykańskim ${ }^{47}$. Trudności $z$ jednoznacznym stwierdzeniem bezpośredniości obserwacji zawartych w źródłach potwierdza również analiza materiału źródłowego do dziejów bibliotek w Polsce w pierwszej połowie XX w.

W dalszej części artykułu H. McMullen skupił się na krytyce i ocenie użyteczności źródeł prymarnych w historii bibliotek, podkreślając konieczność ich właściwego, fachowego, uczciwego i solidnego wykorzystania. Jego opracowanie powstało jako swego rodzaju podręcznik dla bibliotekarzy zajmujących się historią książnic. H. McMullen stwierdził, że bibliotekarze w swojej codziennej pracy stają się współtwórcami źródeł prymarnych, np. dokumentacji bibliotecz-

\footnotetext{
${ }^{43}$ Sources and Historiography - analiza publikacji na temat źródeł do historii bibliotek zamieszczana na łamach ,Journal of Library History” i „Libraries et Culture” w artykułach publikowanych, co kilka lat, pt. The Literature of American Library History.

${ }^{44}$ Np. M. H. Harris, A Guide to Research in American Library History, Metuchen, New Jersey 1968 (drugie wydanie 1974).

${ }^{45}$ Por. Research Methods in Librarianship. Historical and Bibliographical Methods, ed. R. E. Stevens, Urbana 1971 s. 23-41. W tym samym tomie ukazał się artykuł poświęcony krytyce źródeł pisanych, badaniu ich wiarygodności i autentyczności, autorstwa E. G. Holleya, Textual Criticism in Library History..., s. 95-105.

${ }^{46}$ H. McMullen, Primary Sources in Library Research ..., s. 27.

${ }^{47}$ Zob. m.in.: J. M. Tszucker, Clio's Workshop: Resources for Historical Studies in American Librarianship, „Libraries and Culture”, 2000, 35, nr 1, s. 199.
} 
nej i słusznie podkreślił, że powinni mieć tego świadomość i starać się, aby stanowiły one rzeczywiste źródło wiedzy dla historyków. Stwierdził, że historycy książnic, mający praktykę biblioteczną, dysponują wiedzą na temat powstawania źródeł dokumentujących działalność bibliotek, dlatego nie muszą wykorzystywać np. dyplomatyki przy krytyce źródeł. Jednocześnie zwrócił uwagę na jednak niski poziom prac historycznych bibliotekarzy praktyków wynikający $z$ nieumiejętnego wykorzystywania źródeł historycznych. Upatrywał przyczyny tego stanu rzeczy w oczywistym fakcie, że im dalej w przeszłość sięgają badania tym wiedza wynikająca $z$ praktyki bibliotecznej ma mniejsze znaczenie ${ }^{48}$ - należy dodać, że wzrasta rola znajomości metodologii historii i jej nauk pomocniczych, w tym źródłoznawstwa.

Wśród specyficznych cech źródeł do historii bibliotek H. McMullen zwrócił uwage przede wszystkim na odmienność terminologii bibliotekarskiej stosowanej w różnych językach. Jej właściwe zrozumienie sprawia niekiedy duże trudności historykom, choćby $z$ tego powodu, że na przestrzeni wieków znaczenie niektórych pojęć uległo zmianie ${ }^{49}$. Należy dodać, że zasób specyficznych źródeł do dziejów bibliotek jest znacznie bogatszy, co można stwierdzić np. na podstawie materiałów do historii książnic w Polsce w pierwszej połowie XX w. Zasób ten obejmuje m.in.: księgozbiory, znaki własnościowe i noty proweniencyjne; część dokumentacji bibliotecznej, w tym katalogi i inwentarze; część budowli, lokali i wyposażenia bibliotecznego oraz formy organizacyjne bibliotek.

Odnośnie krytyki źródeł H. McMullen wskazał przede wszystkim na konieczność badania wiarygodności źródła, celu, intencji i postawy jego wytwórcy wobec opisywanych wydarzeń. Stwierdził m.in., że w ocenie źródeł winny obowiązywać następujące zasady:

- im mniejsza jest grupa odbiorców źródła, tym większe jest prawdopodobieństwo jego wiarygodności;

- im bliższa jest w czasie relacja do wydarzenia, które źródło opisuje, tym większe jest prawdopodobieństwo jej prawdziwości;

- źródło tworzone dla potomności jest mniej wiarygodne niż tworzone dla współczesnych;

- informacja źródłowa ma wartość naukową, o ile zostanie potwierdzona przez inne, niezależne źródło ${ }^{50}$.

Naturalnie wyżej cytowane stwierdzenia nie wyczerpują problemów zewnętrznej i wewnętrznej krytyki źródeł historycznych. Autor starał się w swoim artykule przekazać podstawowe, praktyczne informacje w tym zakresie. Oparł je na analizie wykorzystania źródeł w piętnastu opracowaniach $z$ zakresu historii bibliotek oraz na własnych badaniach dotyczących książnic działających w Stanach Zjednoczonych Ameryki przed 1876 r. H. McMullen przedstawił także rezultaty własnych badań statystycznych odnoszących się do częstotli-

\footnotetext{
${ }^{48}$ H. McMullen, Primary Sources in Library Research..., s. 24.

${ }^{49}$ Tamże, s. 27.

${ }^{50}$ Tamże, s. 29-31.
} 
wości wykorzystania źródeł prymarnych i wtórnych w owych opracowaniach, zdając sobie sprawę $z$ niereprezentatywności próby ${ }^{51}$.

Do najbardziej wiarygodnych źródeł prymarnych H. McMullen zaliczył:

- Materiały rękopiśmienne, których główną wadą według niego jest to, że zanim historykowi uda się uzyskać $z$ nich istotną informację, jest zmuszony do przejrzenia dużej ilości materiałów. Wymienił w tym kontekście:

a) korespondencję prywatną, której właściwa interpretacja wymaga znajomości biografii i intencji korespondentów. Autor zwracał uwagę także na to, że urzędowa korespondencja biblioteczna ma charakter formalny, konwencjonalny, który maskuje prawdziwe uczucia, poglądy autora źródła. H. McMullen podkreślał, że historyk często dysponuje tylko źródłami jednostronnymi tj. korespondencją otrzymaną przez adresata listów;

b) odręczne spisy wypożyczeń, rewersy, to według autora wiarygodne źródła, gdyż informują o realnym funkcjonowaniu biblioteki i jej zbiorach.

H. McMullen uwypuklił trudności we właściwym odczytaniu materiałów rękopiśmiennych oraz to, że cechują się niekiedy małą precyzją np. w zapisach tytułów wypożyczanych książek ${ }^{52}$.

Omawiając materiały rękopiśmienne autor pominął jednak wiele grup źródeł dokumentujących działalność bibliotek i ich księgozbiory, np. inwentarze. Nie scharakteryzował wyczerpująco cech korespondencji prywatnej, którą przecież uznał za najbardziej wiarygodną. Dlatego wypada dodać, że za szczególnie cenną należy uznać korespondencję, która jest ściśle związana $z$ badaną problematyką, w naszym przypadku $z$ historią bibliotek. Marian Łodyński tak przedstawiał jej naturę w liście do Adama Łysakowskiego: „Piszę prywatnie, chociaż w sprawie urzędowej. Jak wiadomo, niejednokrotnie urzędowe sprawy tak ściśle wiążą się z prywatnymi, czy té̇ prywatno-publicznymi, że przy urzędowym załatwieniu niepodobna ich dostatecznie ściśle rozgraniczyć" ${ }^{33}$. Zaiste, w „bibliotekarskiej” korespondencji historyk znajdzie obraz wszelkich spraw urzędowych i nieurzędowych, którymi żyli nie tylko autorzy listów, ale i ich środowisko. Ôw obraz bywa niekiedy aż nadto subiektywny, nieszczery, zniekształcony i emocjonalny, ale stanowi przekaz, którego historyk nie może zlekceważyć, zwłaszcza, że poufność wypowiedzi epistolarnej - a raczej przekonanie korespondentów o poufności listów - umożliwiała przekazywanie informacji, których nie znajdziemy w innych źródłach do dziejów książnic. Takie informacje zawierają np. prywatne listy opublikowane przez Marię Dembowską w Bibliotekarstwie polskim... 1925-1951, mimo skrótów zastosowanych przez autorkę edycji. Niejednokrotnie stanowią one również nieocenioną pomoc przy krytyce źródeł pisanych wytwarzanych w środowisku polskich bibliotekarzy naukowych w la-

51 Tamże, s. 25.

${ }^{52}$ H. McMullen, Primary Sources in Library Research..., s. 37-38.

${ }^{53}$ List z 3 kwietnia 1936 r., zob.: Bibliotekarstwo polskie 1925-1951 w świetle korespondencji jego współtwórców, wyboru z listów Adama Łysakowskiego, Mariana Łodyńskiego, Józefa Grycza i Heleny Hleb-Koszańskiej dokonała, wstępami, przypisami i indeksem opatrzyła M. Dembowska, Warszawa 1995, s. 107. 
tach 1925-1947. Ujawniają deklarowane motywacje części autorów źródeł, okoliczności, w których źródła powstały, ich kontekst, to, co w nich subiektywne i tendencyjne (subiektywizm i tendencja wynikała $z$ przesłanek merytorycznych, ale także m.in. $z$ konfliktów, niechęci osobistych) oraz to, co zostało pominięte, lub ukryte w źródle „między wierszami”.

- Wywiady (tzw. oral history), aczkolwiek stanowią według H. McMullena ważny materiał źródłowy, gdy przeprowadzane są $z$ naocznymi świadkami czy uczestnikami niedawnych wydarzeńn ${ }^{4}$, to jednak należy brać pod uwagę nastawienie, ukryte intencje, subiektywizm i emocjonalne nacechowanie źródła, a w przypadku wywiadów przeznaczonych do publikacji jego nieszczerość w wypowiedziach na temat osób lub instytucji, $z$ którymi źródło było lub jest związane. Nastawienie źródła do opisywanych przez nie wydarzeń jest według autora tym bardziej rozpoznawalne, im większą rolę w opisywanych wydarzeniach odegrało to źródło. Podstawową zasadą, która powinna towarzyszyć badaczowi prowadzącemu wywiad brzmi według H. McMullena następująco: chcesz się czegoś dowiedzieć na temat interesującego cię faktu - pytaj o co innego ${ }^{55}$.

Trudno się jednak zgodzić $z$ opinią autora, że źródła tego typu są wiarygodniejsze od innych, przeciwnie, powinno się je wykorzystywać $z$ równą ostrożnością jak np. źródła literackie (autor zaliczył do nich: wspomnienia, dzienniki, diariusze), które zdaniem H. McMullena cechują się dosyć niską wiarygodnością ${ }^{56}$. Przy czym warto podkreślić, że wywiad może być wartościowym źródłem informacji na temat niepisanego obyczaju, tradycji i kultury organizacyjnej badanej biblioteki ${ }^{57}$.

- Artefakty (pozostałości): zbiory biblioteczne, ich fragmenty i pojedyncze książki, np. książki (w sensie materialnym, fizycznym) ze znakami własnościowymi $^{58}$; wyposażenie; budynki i ikonografia. W odróżnieniu od materiałów rękopiśmiennych H. McMullen zaliczył artefakty do rzeczywistych źródeł prymarnych, gdyż w ich przypadku między faktem, a historykiem nie stoi żaden pośrednik poza ignorancją badacza. Aby właściwie odczytać źródła tego typu, zrozumieć ich przeznaczenie, historyk bibliotek musi się niejednokrotnie odwoływać do źródeł pisanych: np. w przypadku niektórych

${ }^{54}$ H. McMullen, Primary Sources in Library Research..., s. 38.

${ }^{55}$ Tamże.

${ }^{56}$ Tamże, s. 31.

${ }^{57}$ Przykładem może być litera „T” umieszczona przed sygnaturą na niektórych kartach katalogowych Biblioteki Polskiej Akademii Nauk w Warszawie. Dopiero z ustnych informacji bibliotekarzy Barbara Słomczewska dowiedziała się, że litera „T” wskazywała na przynależność książki do dawnej Biblioteki Centralnej Towarzystwa Naukowego Warszawskiego, utworzonej w 1908 r., a przejętej przez PAN w 1958 r. Zob. B. Słomczewska, Sieć bibliotek Towarzystwa Naukowego Warszawskiego w latach 1907-1952, „Z Badań nad Polskimi Księgozbiorami Historycznymi” 1977 z. 3 s. 107, 138.

${ }^{58} \mathrm{~W}$ innym artykule H. McMullen stwierdził, że znaki własnościowe same w sobie można uznać warunkowo za źródła prymarne, zob. H. McMullen, Probate Records as a Source of American Library History, w: Proceedings of the Fourth Library History Seminar, ed. H. Goldstein, J. Goudeau, Tallahassee 1972, s. $140-149$. 
urządzeń bibliotecznych lub w przypadku „odczytywania” budynków bibliotecznych (,odczytanie” budynku jako źródła polega m.in. na prawidłowym określeniu czasu jego powstania, zdefiniowaniu jego pierwotnych funkcji, rekonstrukcji prac adaptujących go do funkcji bibliotecznych itp.) Również źródła ikonograficzne wymagają często konfrontacji ze źródłami pisanymi, aby je można było właściwie odczytać. H. McMullen zwracał przy tym uwagę na konieczność szczególnie krytycznego spojrzenia na fotografię jako źródło wskazując na to, że może być myląca ze względu na konwencję artystyczną ${ }^{59}$, nie wspominając o świadomych fałszerstwach, spotykanych w tej grupie źródeł.

W mojej opinii pozostałości po księgozbiorach należy traktować jako źródła pośrednie między pisanymi i niepisanymi. Materialna postać książki, pochodzącej $z$ określonej kolekcji bibliotecznej, stanowi źródło niepisane, którego cechy wydawnicze i nabyte (np. brak oprawy bibliotecznej, uszkodzenia, brak śladów konserwacji) mogą badaczowi dostarczyć informacji m.in. o możliwościach finansowych biblioteki. $Z$ drugiej zaś strony książka jest źródłem pisanym, informującym o profilu tematycznym księgozbioru, a także źródłem do badań czytelnictwa (rękopiśmienne glosy do tekstu stanowią świadectwo recepcji czytelniczej). Jako źródło do historii bibliotek książka stanowi zatem całość, złożoną $z$ integralnie ze sobą powiązanych, pisanych i niepisanych warstw, których nie powinno się rozpatrywać $z$ osobna.

Trudno również jednoznacznie zakwalifikować do źródeł pisanych bądź niepisanych superekslibrisy i ekslibrisy, które oprócz wyobrażenia ikonograficznego zawierają tekst pisany (np. monogram właściciela książki w superekslibrisach czy jego nazwisko w ekslibrisach, a także dewizy, sentencje i motta).

Wśród źródeł prymarnych najczęściej wykorzystywanych przez historyków bibliotek, ale równocześnie cechujących się mniejszą wiarygodnością od wyżej wymienionych H. McMullen wymieniał:

- Rękopiśmienne i publikowane dokumenty legislacyjne. Zgadzając się $z$ oceną, że generalnie rzecz biorąc są to jedne $z$ najbardziej wiarygodnych źródeł historycznych, autor zwracał uwagę, że w przypadku historii bibliotek amerykańskich wiele materiałów tego typu charakteryzuje się małą wiarygodnością, zwłaszcza dokumenty związane $z$ pracami legislacyjnymi, takie jak np. opinie, dezyderaty środowiska bibliotekarskiego. Są one $z$ natury rzeczy nieobiektywne, nacechowane skłonnością do przesadnego eksponowania roli bibliotek i obrony własnych interesów środowiskowych.

$\mathrm{Z}$ podobnego punktu widzenia można równiė̇ oceniać polską, międzywojenną kampanię części środowiska bibliotekarskiego na rzecz uchwalenia ustawy bibliotecznej ${ }^{60}$. Kolejny problem zauważony przez H. McMullena to konieczność weryfikowania zapisów legislacyjnych $z$ ich realnym wpływem na rzeczywis-

${ }^{59}$ H. McMullen, Primary Sources in Library Research ..., s. 37-39.

60 Problem ustawy bibliotecznej szczegółowo omówiła Jadwiga Kołodziejska w opracowaniu: Publiczne biblioteki samorzq̨dowe w okresie międzywojennym, Warszawa 1967, s. 29-97. 
tośćc1 ${ }^{61}$ Z punktu widzenia badacza źródeł np. do dziejów książnic II Rzeczypospolitej można dodać, że takiej ocenie powinny podlegać wszelkie akty ustawodawcze, uchwały i rozporządzenia wykonawcze, a także akty prawa miejscowego, okólniki, instrukcje, wytyczne „zewnętrznych” instytucji, które miały wpływ na działalność bibliotek.

- Oficjalne, publikowane dane statystyczne na temat działalności bibliotecznej: według H. McMullena cechują się małą wiarygodnością, bowiem prezentują takie liczby, jakie chcieli ujawnić bibliotekarze; ponadto, w większości przypadków, mogą być niedokładne. Wskazują na to częste zaokrąglenia (w przypadku bibliotek amerykańskich do tysiąca) danych liczbowych odnoszących się do zbiorów bibliotecznych. Inne błędy źródeł tego typu, wymieniane przez autora, to pomyłki powstałe przy przygotowywaniu publikacji na podstawie materiałów rękopiśmiennych. Dotyczą m.in. danych liczbowych, opisów bibliograficznych, dat wydania dzieł ${ }^{62}$.

Warto jednak nadmienić, że np. w przypadku źródeł do dziejów książnic II Rzeczypospolitej $z$ podobną sytuacją mamy do czynienia zazwyczaj w przypadku danych statystycznych publikowanych przez instytucje sprawujące nadzór nad bibliotekami lub instytucje statystyczne. Sprawozdania biblioteczne, wydawane przez same biblioteki lub pod ich kontrolą, cechują się natomiast stosunkowo większą precyzją danych i zgodnością wersji drukowanych i rękopiśmiennych (oczywiście ostatecznych wersji rękopiśmiennych).

- Informacje źródłowe w zespołach akt generalnie nie odnoszących się do

kwestii bibliotecznych: H. McMullen zwraca uwagę na to, że w archiwach instytucji nadzorujących biblioteki można znaleźć informacje odnoszące się do ich działalności. Jako przykład wymienił dokumentację finansową ${ }^{63}$.

W przypadku bibliotek II Rzeczypospolitej podobna dokumentacja oprócz finansowej obejmuje wiele innych grup źródeł odnoszących się do: księgozbiorów, spraw osobowo-płacowych, wyposażenia i budynków bibliotecznych, kwestii prawnych, użytkowników bibliotek itp. Potencjalną użyteczność materiałów tego typu potwierdzają równie $\dot{z}$ badania niemieckie. Świadczy o tym m.in. kwerenda przeprowadzona w państwowych, kościelnych oraz prywatnych archiwach Wirtembergii w ramach programu Erschliessung von Quellen zur Bibliotheks- und Buchgeschichte, realizowanego w Niemczech od 1985 do 1996 r. Przyniosła ona bogaty materiał do dziejów bibliotek ludowych w Królestwie Wirtembergii w XIX i XX w. - w postaci: oficjalnej i prywatnej korespondencji, protokołów posiedzeń różnorakich gremiów, poleceń służbowych, okólników, danych statystycznych, sprawozdań rocznych, pism okolicznościowych, zarządzeń cenzury, przesłuchań policyjnych, różnego rodzaju katalogów zbiorów, materiałów administracyjnych, rachunków, regulaminów wypożyczeń itp. - mimo, że więcej niż połowa interesujących dokumentów była zarchiwizowana jako

\footnotetext{
${ }^{61}$ H. McMullen: Primary Sources in Library Research..., s. 33-35.

${ }^{62}$ Tamże, s. 35.

${ }^{63}$ Tamże, s. 36.
} 
materiał administracyjny, w którym na pierwszy rzut oka nie podejrzewano istnienia źródeł do historii bibliotek ${ }^{64}$. Przy czym należy podkreślić, że materiały tego rodzaju są zazwyczaj rozproszone i zróżnicowane pod względem naukowej użyteczności. Ich wyszukanie wymaga często drobiazgowej i rozległej kwerendy, która może przynieść nikłe rezultaty badawcze. Na przykład w zachowanych aktach finansowych Warszawskiego Towarzystwa Dobroczynności (WTD), prowadzącego w drugiej połowie XIX w. czytelnie bezpłatne, można znaleźć informacje dotyczące wydatków na sierocińce, przedszkola itp., zaś na temat finansowania bibliotek, poza nielicznymi wyjątkami, wcale ${ }^{65}$. Wartościowe materiały dotyczące finansów czyteln WTD znajdują się w Archiwum Biblioteki Publicznej m. st. Warszawy (ABP) ${ }^{66}$.

- Drukowane katalogi biblioteczne: tą grupę źródeł H. McMullen uważa za relatywnie miarodajną, bowiem ich forma i zawartość, w tym szczegółowość opisów katalogowych, były dostosowane do potrzeb ich użytkowników, stanowiły dla nich podstawowe źródło informacji o zbiorach bibliotecznych dlatego ich wiarygodność była weryfikowana na bieżąco. Według autora nie można tego samego powiedzieć o poprzedzających katalogi wstępach, które nie zawsze opisują rzeczywistą działalność bibliotek ${ }^{67}$.

Badania nad źródłami do dziejów bibliotek w Polsce w pierwszej połowie XX w. wskazują jednak, że katalogi w części opisującej zbiory, także winny podlegać krytyce, np. ze względu na możliwe błędy w opisach. Ponadto godzi się wspomnieć o tym, że drukowane katalogi nie zawsze oddawały rzeczywisty stan księgozbiorów bibliotek (szczególnie w przypadku dużych, różnorodnych zbiorów) opisując niejednokrotnie tylko te zbiory, które były udostępnione do publicznego użytkowania.

- Sprawozdania roczne bibliotek: należy je traktować szczególnie ostrożnie. Według H. McMullena części sprawozdań dużych bibliotek nie można nawet zakwalifikować do grupy źródeł prymarnych ze względu na ich kompilacyjną strukturę, dygresje odnoszące się do ogólnego stanu bibliotekarstwa w danym czasie i miejscu, często formułowane na podstawie opinii $z$ „drugiej ręki” ${ }^{6}$. Można do tego dodać autokreację twórców sprawozdań, podnoszenie rangi działalności macierzystej biblioteki itp.

Ogólnie rzecz ujmując H. McMullen ocenił publikowane sprawozdania biblioteczne jako źródła najmniej wiarygodne. Uważam, że jest to opinia zbyt da-

\footnotetext{
${ }^{64}$ U. Hohoff, Quellen zur Geschichte der Volksbibliotheken ins Württemberg und Hohenzollern $1806-$ 1918. Ein Pilotprojekt der DFG [Deutsche Forschungsgemeinschaft] zur Erschliessung historischer Quellen über die „Literaturversorgung” einzelner Regionen, Zeitschrift für Bibliothekswesen und Bibliographie, 1988, 35, s. 488-489.

${ }^{65}$ J. Rudnicka, Wstęp, w: Archiwum Biblioteki Publicznej m. st. Warszawy. Akta nr 1-245, oprac. J. Rudnicka, J. Górka, K. Sokołowska-Grzeszczyk, Warszawa 1977, s. 8.

${ }^{66}$ ABP, Akta Sekcji Czytelń Bezpłatnych przy Warszawskim Towarzystwie Dobroczynności. 18621872, sygn. A. 1.

${ }^{67}$ H. McMullen, Primary Sources in Library Research..., s. 36.

${ }^{68}$ Tamże.
} 
leko idąca. Należy badać wszystkie warstwy informacyjne sprawozdań w ich poszczególnych częściach, bowiem jedne mogą być bardziej wiarygodne (np. dane finansowe) inne mniej (np. fragmenty opisowe, interpretujące dane).

- Artykuły w czasopismach: H. McMullen stwierdził, że są równie mało wiarygodne jak sprawozdania roczne bibliotek. Ocenił, że ich podstawową wadą jest to, że należą do źródeł skierowanych do potomności oraz, że trudno rozstrzygnąć, czy informacje podawane w tekstach artykułów mają charakter pierwotny (prymarny), czy wtórny ( $z$ drugiej ręki). Równie trudno określić uwarunkowania $\mathrm{w}$ jakich powstawały teksty i w jakim stopniu wpływały one na treść artykułów (autocenzura, redakcja). H. McMullen podkreślił, że w artykułach bibliotekarzy amerykańskich czytelna jest intencja ich autorów podkreślanie i podnoszenie społeczno-kulturowej rangi bibliotek ${ }^{69}$.

W charakterystyce źródeł prasowych autorstwa H. McMullena zabrakło przede wszystkim ich pogłębionej analizy z prasoznawczego punktu widzenia. Poprawna metodologicznie ocena źródeł tego rodzaju pomaga m.in. w identyfikacji informacji pierwotnych i uwarunkowań, w których wytworzono badane informacje źródłowe ${ }^{70}$.

- Źródła „quasi rękopiśmienne”: rękopiśmienne kopie maszynopisów, prywatne notatki $z$ dokumentów służbowych, często nie datowane, bez tytułów wg H. McMullena są to źródła niezwykle trudne do wykorzystania ${ }^{71}$.

Podsumowując, w wielu kwestiach można zgodzić się H. McMullenem, zwłaszcza w zakresie konieczności selekcji źródeł $z$ punktu widzenia ich naukowej użyteczności, badania wiarygodności twórcy źródła, jego drogi życiowej, doświadczenia bibliotekarskiego, kompetencji - wielokrotnie weryfikowanych w trakcie jego kariery zawodowej. Równie istotna dla oceny źródeł zdaniem H. McMullena jest wiedza o organizacji bibliotekarstwa w badanym okresie, np. o stosowanych systemach katalogowania i wszelkich zmianach w tej dziedzinie $^{72}$. Omawiany artykuł nie wyczerpuje jednak problematyki źródeł do historii książnic XIX i XX w., co sygnalizowałem - na przykładzie źródeł do dziejów bibliotek w Polsce w pierwszej połowie XX w. - prezentując i komentując poglądy H. McMullena na temat wyróżnionych przez niego grup źródeł.

\footnotetext{
${ }^{69}$ Tamże, s. 37.

${ }^{70} \mathrm{~W}$ przypadku polskiej literatury przedmiotu odnoszącej się do problematyki źródeł prasowych XIX i XX w., można wymienić takie pozycje jak: K. Bobowski, K. Burski, B. Turoń, Encyklopedia nauk pomocniczych historii nowożytnej i najnowszej, Wrocław 1976, s. 173; J. Myśliński, Uwagi o prasie polskiej przełomu XIX/XX w. jako źródle historycznym, „Rocznik Historii Czasopiśmiennictwa Polskiego”, 1974, t. 14, z. 1, s. 5-26; R. Wapiński, Problemy źródłoznawcze badań prasoznawczych, w: Werbalne i pozawerbalne środki wyrazu w źródle historycznym. Materiały z II Sympozjum Nauk Dających Poznawać Źródła Historyczne - problemy warsztatu historyka, red. R. Rosin, J. Szymański, Lublin 1981, s. 108-116. Zob. także: M. Kafel, Prasoznawstwo. Wstęp do problematyki, wyd. 2, Warszawa 1969; A. Paczkowski, Prasa polska $w$ latach 1918-1939, Warszawa 1980; S. Dziki, Warsztat dokumentacyjny prasoznawcy. Problemy teoretyczno-metodologiczne, tradycje, stan, postulaty, Wrocław, Kraków 1992.

${ }^{71}$ H. McMullen: Primary Sources in Library Research..., s. 37.

${ }^{72}$ Tamże, s. 28-30.
} 
W tym samym tomie, co opracowanie H. McMullena, ukazał się artykuł L. J. Batesa pt. The Importance of Using Primary Sources in Historical Research, również napisany $z$ myślą o historykach bibliotek ${ }^{73}$. Autor stwierdził w nim m. in., że o wartości źródeł decyduje ich zawartość, naukowa użyteczność a nie oryginalność. Podał tutaj przykład maszynowej kopii rękopiśmiennego, pokreślonego, poplamionego oryginału. Jeśli kopia jest zgodna $z$ tekstem oryginału stanowi użyteczniejsze źródło dla historyka ${ }^{74}$. Można się zgodzić $z$ tą opinią tylko w przypadku, gdy wspomniane przez L. J. Batesa skreślenia są nieistotne, nie stanowią same w sobie ważnej informacji źródłowej dla badanego problemu. Inna sprawa, że owe skreślenia i stan zachowania źródła mogą nam wiele powiedzieć o jego twórcy i o znaczeniu źródła dla osób i instytucji, które je wykorzystywały.

L. J. Bates podzielił źródła na prymarne i wtórne, do których zaliczył wszelkie publikowane i niepublikowane opracowania, nadmieniając przy tym, że źródła wtórne zawierają niekiedy również informacje źródłowe o charakterze prymarnym. Źródła prymarne podzielił na drukowane i rękopiśmienne stwierdzając, ze jest to podział dychotomiczny i powszechnie stosowany (przede wszystkim w dysertacjach akademickich, np. pracach magisterskich). Do źródeł rękopiśmiennych zaliczył spuścizny prywatne, źródła archiwalne, wywiady i miscellanea; do źródeł drukowanych: publikacje urzędowe, autobiografie i wspomnienia, zbiory mów i listów, artykuły $z$ czasopism. Wyróżnione grupy źródeł L. J. Bates podzielił na trzy kategorie, wyodrębnione według własnego rankingu ich wartości, konstatując, że wartość naukowa źródeł zależy od celu w jakim mają być użyte ${ }^{75}-$ np. źródła istotne dla historyka bibliotek nie muszą być równie ważne dla historyków zajmujących się inną problematyką.

Za najcenniejsze wśród źródeł rękopiśmiennych L. J. Bates uznał spuścizny prywatne uczestników badanych wydarzeń, tworzone na bieżąco lub w czasie, kiedy opisywane wydarzenia były jeszcze żywe w pamięci autora źródła. Przy czym spuściznę rozumiał, jako określoną całość, tj. kolekcję złożoną $z$ różnych materiałów: dokumentacji aktowej, korespondencji, tekstów przemówień, wycinków prasowych i publikacji, podkreślając szczególną wagę korespondencji prywatnej, której wartość ocenił jako zróżnicowaną - w zależności od nadawcy listu, jego pozycji społecznej, motywacji i kompetencji ${ }^{76}$. Trudno zatem zaliczyć podobne kolekcje do grupy źródeł rękopiśmiennych, zgadzając się jednak $z$ L. J. Batesem, że zachowane i kompletne (obejmujące zarówno materiały rękopiśmienne jak i drukowane) spuścizny prywatne mogą być dla historyka bibliotek nieocenionym źródłem historycznym.

L. J. Bates ocenił, że dla części tematów badawczych najwartościowszą grupę źródeł stanowią materiały archiwalne obejmujące całe spektrum działalnoś-

73 L. J. Bates: The Importance of Using Primary Sources in Historical Research. w: Research Methods in Librarianship..., s. 11-21.

${ }^{74}$ Tamże, s. 14.

${ }^{75}$ L. J. Bates, The Importance of Using Primary Sources..., s. 14.

${ }^{76}$ Tamże, s. 14-15. 
ci badanej instytucji ${ }^{77}$. W przypadku historii bibliotek trudno jednak sobie wyobrazić badania opierające się wyłącznie na źródłach aktowych, a pomijające np. pozostałości po księgozbiorach - należy przecież mieć na uwadze, że wszelkie formy działalności książnic wywodzą się $z$ ich podstawowych funkcji: gromadzenia, przechowywania, opracowania i udostępniania zbiorów.

Do szczególnie cennych źródeł L. J. Bates zaliczył wszelkie dokumenty związane $z$ działalnością administracji rządowej i legislatury stwierdzając, że stanowią one bezpośrednie źródło wiedzy na temat badanych wydarzeń ${ }^{78}$. Na konieczność krytycznej oceny źródeł tego rodzaju zwracałem uwagę powyżej.

Do kategorii najwartościowszych źródeł historycznych L. J. Bates zaliczył także czasopisma dziedzinowe, związane tematycznie $z$ badaną problematyką ${ }^{79}$, a przecież nie wszystkie artykuły z czasopism można uznać - wedle przytoczonej wyżej definicji samego autora - za prymarne.

Drugą kategorię, mniej istotną dla historyka, stanowią zdaniem L. J. Batesa źródła prymarne wytworzone przez obserwatorów badanych wydarzeń, a nie ich aktywnych uczestników. Do tej grupy źródeł autor zaliczył np. utwory literatury pięknej, uważając jednak ich wartość za wątpliwą ${ }^{80}$. Trzecią zaś kategorię źródeł prymarnych stanowią według oceny L. J. Batesa przekazy powstałe długo po opisywanym przez nie wydarzeniu i w efekcie posiadające mniejszą wartość niż poprzednie grupy źródeł. Należy do nich część pamiętników, autobiografii i wywiadów, a więc źródła, których wartość zależy od ich autorów ${ }^{81}-$ ich pamięci, intencji, postawy wobec opisywanych wydarzeń, celów, które zamierzali osiągnąć.

W mojej opinii zarówno utwory literatury pięknej, jak i korespondencję prywatną, pamiętniki, wspomnienia, literaturę autobiograficzną itp. należy zaliczyć do źródeł literackich. Ograniczona objętość niniejszego artykułu nie pozwala na ich szczegółową analizę. Warto jednak zwrócić uwagę na to, że kwestia oceny źródeł literackich i ich wykorzystania w badaniach nad historią książki i bibliotek stała się współcześnie przedmiotem rozważań metodologicznych, zarów-

\footnotetext{
77 Tamże, s. 15.

${ }^{78}$ Tamże, s. 15-16.

${ }^{79}$ L. J. Bates, The Importance of Using Primary Sources..., s. 16.

${ }^{80}$ Tamże, s. 17.

${ }^{81}$ Tamże.
} 
no w polskiej ${ }^{82}$, jak i obcej literaturze bibliologicznej ${ }^{83}$. Odnosząc się do oceny wartości źródłowej literatury pięknej sformułowanej przez L. J. Batesa należy podkreślić, że utwory mogą być źródłem informacji o świadomości, wiedzy, zainteresowaniach swoich autorów, o sposobie postrzegania przez nich społecznej roli bibliotek i znaczenia książnic w życiu jednostek.

Jak sam J. Bates przyznaje, problematyka źródeł jest bardziej skomplikowana niż to przedstawił, a jego typologia jest daleka od kompletności ${ }^{84}$. Obejmuje tylko wybrane grupy źródeł pisanych, a ich charakterystyka $z$ punktu widzenia oceny wartości, naukowej użyteczności, jest nie tylko niepełna, ale i fragmentami dyskusyjna, czego dawałem wyraz powyżej.

Do wartych omówienia należą równiė̇ rozważania na temat źródeł do dziejów bibliotek autorstwa R. Krzysa. Jest on m.in. autorem hasła Library Historiography zamieszczonego w Encyclopedia of Library and Information Science ${ }^{85}$ zawierającego obszerny zarys problematyki historiografii bibliotek. Według R. Krzysa o charakterze współczesnej historii bibliotek decyduje m.in. to, że:

- jest domeną wyspecjalizowanych w historii bibliotekoznawców;

- jest gałęzią historii ogólnej, zatem historyka bibliotek obowiązuje metodologia historii (należy jednak dodać, że w przypadku źródeł wywołanych, współtworzonych przez historyka, istnieje konieczność korzystania $z$ dorob-

${ }^{82} \mathrm{Na}$ temat pamiętników (oraz różnic między literaturą pamiętnikarską a wspomnieniową) w badaniach bibliologicznych zob. m.in.: S. Siekierski, Pamiętniki jako źródło badań czytelnictwa, „Studia o Książce” 1976, t. 6, s. 3-22; K. Bednarska-Ruszajowa, Biblioteki i książki w pamiętnikach polskich XVIIXX wieku. Rekonesans źródłowy, Kraków 2003.

Zob. także: Encyklopedia nauk pomocniczych..., s. 89-90; J. Trzynadlowski, Struktura relacji pamiętnikarskiej, w: Księga pamiątkowa ku czci Stanisława Pigonia, Kraków 1961, s. 577-583; Cz. Madajczyk, Źródła w historii najnowszej, „Studia Źródłoznawcze”, 1972, t. 17, s. 1-7; I. Ihnatowicz, Problemy edytorstwa pamiętników jako źródeł dla historii najnowszej, „Pamiętnikarstwo Polskie”, 1974, nr 1-2, s. 135-144; A. Cieński, Kryteria oceny prozy pamiętnikarskiej, „Pamiętnik Literacki”, 1975, z. 2, s 17-36; I. Ihnatowicz, Nauki pomocnicze historii XIX i XX wieku, Warszawa 1990, s. 148-156; Z. Wójtkowiak, Nauki pomocnicze historii najnowszej. Źródłoznawstwo. Źródła narracyjne. Cz. 1, Pamiętnik, tekst literacki, Poznań 2003.

Na temat literatury pięknej w badaniach bibliologicznych zob. m.in.: Biblioteki i książki w literaturze, red. nauk. K. Bednarska-Ruszajowa, Kraków 1998, M. Stolzman, Dzieło literackie jako źródło wiedzy o książce, w: Z historycznych i metodologicznych problemów..., s. 37-54; A. Dróżḋ̇, Literatura piękna jako źródło wiedzy o książe i bibliotece. EBIB, 2002, nr 33 [dokument elektroniczny]

http://ebib.oss.wroc.pl/2002/33/drozdz.php; K. Bednarska-Ruszajowa, Pamiętniki a teksty literackie jako źródło do badań nad ksiażkq i bibliotekq, w: eadem: Biblioteki i ksiqżki..., s. 131-133.

Zob. także: Dzieło literackie jako źródło historyczne, red. Z. Stefańska i J. Sławiński, Warszawa 1978.

${ }^{83}$ Zob. m.in.: K. Bednarska-Ruszajowa, Światowe badania nad opisami bibliotek w utworach literackich, w: Biblioteki i książki w literaturze, red. nauk. K. Bednarska-Ruszajowa, Kraków 1998, s. 9-17; oraz aneksy: Aneks A. Światowe badania nad opisami bibliotek $w$ utworach literackich. Bibliografia, w: tamże, s. 17-25; Aneks B. Biblioteki w zagranicznych utworach literackich XIX i XX wieku. Bibliografia, w: tamże, s. 25-54; Bibliotheken in der literarischen Darstellung = Libraries in literature, hrsg. P. Vodosek, G. Jefcoate, Wiesbaden 1999.

${ }^{84}$ L. J. Bates, The Importance of Using Primary Sources..., s. 17.

${ }^{85}$ R. Krzys, Library Historiography, w: Encyclopedia of Library and Information Science, ed. M. A. Drake, New York, Basel 2003, s. 1624-1638. 
ku metodologii nauk społecznych), a zarazem jest nauką interdyscyplinarną, sytuując się między humanistyką a naukami społecznymi;

- wykorzystuje nauki pomocnicze historii (zaliczając do nich archeologię, epigrafię, paleografię, sfragistykę, numizmatykę, filatelistykę, genealogię, heraldykę, chronologię historyczną i dyplomatykę ${ }^{86}$, R. Krzys pominął m.in. źródłoznawstwo, archiwistykę, bibliografię, prasoznawstwo, statystykę historyczną, czy tak specyficzne nauki pomocnicze historii książki i bibliotek jak np. oprawoznawstwo, czy kodykologia) ${ }^{87}$;

- rzadkość metodologicznie poprawnych opracowań naukowych, wynikająca $z$ braku historycznego wykształcenia bibliotekarzy podejmujących tematykę $z$ zakresu historii bibliotek ${ }^{88}$.

Takie ujęcie historiografii książnic wpływa na poglądy źródłoznawcze R. Krzysa, który poświęca stosunkowo dużo miejsca - w obrębie hasła Library Historiography - typologii źródeł (,evidence”) i ich krytyce. Na wstępie stwierdza, że analiza źródeł, ich natury, ich poszczególnych typów oraz ich autentyczności, ma najważniejsze, zasadnicze znaczenie.

R. Krzys dzieli źródła historyczne na prymarne i wtórne. Wśród źródeł prymarnych wymienia artefakty (zabytki, pozostałości), które według części badaczy są źródłami o największym stopniu wiarygodności. R. Krzys zwraca jednak słusznie uwagę, że wnioski formułowane przez historyków na podstawie źródeł tego typu nacechowane są subiektywną interpretacją - można dodać, że często błędną m.in. w skutek ignorancji w dziedzinie historii książki i bibliotek. R. Krzys posługuje się tutaj przykładem Księgi $z$ Kells, której przetrwanie do czasów współczesnych stanowi dowód na jednostkowy, nietypowy charakter tego zabytku. Na podstawie rękopisu $z$ Kells badacz nie znający specyfiki źródeł do historii bibliotek, ani ich zasobu mógłby wyciągnąć fałszywy wniosek, że podobne, bogato zdobione średniowieczne kodeksy iluminowane, stanowiły standard dla ówczesnej książki, podczas gdy w istocie większość produkcji rękopiśmienniczej była, według określenia amerykańskiego historyka, „siermiężna”"

Zgadzając się $z$ rozważaniami R. Krzysa nalė̇y zwrócić uwagę równiė̇ na to, że historyk bibliotek wykorzystujący księgozbiory, ich fragmenty lub pojedyncze obiekty jako źródła, powinien mieć świadomość, że przetrwanie pozostałości może stanowić wynik różnych okoliczności. Na przykład w historii polskich bibliotek $z$ pierwszej połowy XX w., i nie tylko, mamy do czynienia $z$ pozostałościami planowo lub przypadkowo „wyselekcjonowanymi”. Planowe selekcje dokonywane były przez:

- właścicieli przedwojennych księgozbiorów i bibliotekarzy, którzy wycofywali ze zbiorów książki zaczytane i zdezaktualizowane, dokonywali darowizn,

\footnotetext{
${ }^{86}$ Tamże, s. 1624-1625.

${ }^{87}$ Warto nadmienić, że interesującą propozycję określenia zespołu nauk pomocniczych bibliologii, w tym historii bibliotek, sformułował Piotr Dymmel w artykule: Nauki pomocnicze bibliologii. Zarys problematyki. „Roczniki Biblioteczne” 1984 s. 277-294.

${ }^{88}$ R. Krzys, Library Historiography..., s. 1638.

${ }^{89}$ Tamże, s. 1627.
} 
wymian i wyprzedaży dubletów, innymi słowy pozbywali się książek niepotrzebnych. $Z$ drugiej strony, poprzez szczególną opiekę, starano się zachować najcenniejsze obiekty. Ten rodzaj selekcji daje nam mniejszy lub większy stopień pewności, że zachowane książki były $z$ jakichś powodów bibliolog powinien podjąć próbę ich określenia ważne dla bibliotek i ich właścicieli. Przy czym należy mieć na uwadze, że dużą szansę przetrwania miały jednak książki rzadko używane. Po 1944 r. selekcji ocalałych księgozbiorów przedwojennych książnic dokonywano włączając do zbiorów różnych bibliotek te dzieła, które zdaniem bibliotekarzy były merytorycznie przydatne i które zachowały się w stosunkowo dobrym stanie.

- różne agendy władz. Na przykład po 1 września 1939 r. mamy do czynienia ze świadomym, masowym niszczeniem, grabieżą, rozpraszaniem księgozbiorów i usuwaniem ze zbiorów bibliotek książek uważanych przez okupantów za niepożądane ${ }^{90}$. Świadomych selekcji i rozproszenia ocalałych pozostałości po księgozbiorach dokonywały również (od 1944 r.) władze komunistyczne. Z przypadkową selekcją księgozbiorów, i to w skali masowej, mamy do czynienia po 1 września 1939 r., kiedy to tysiące tomów zostało zniszczonych w skutek działań wojennych, a także przez funkcjonariuszy różnych jednostek i służb armii okupacyjnych, jak również zniszczonych i rozgrabionych przez ludność (zwłaszcza w czasie działań wojennych i po objęciu władzy w Polsce przez komunistów, w okresie nacjonalizacji i reformy rolnej ${ }^{91}$ ).

Ostrożność w formułowaniu wniosków na podstawie pozostałości po księgozbiorach uzasadniają także następujące cechy tego materiału źródłowego:

- zły stan zachowania, np. obecność wśród pozostałości egzemplarzy zdefektowanych, pozbawionych m.in. kart tytułowych. Brak kart tytułowych książek może prowadzić do błędnych wniosków, np. przy określaniu czasu funkcjonowania kolekcji;

- obecność wśród pozostałości nielegalnych przedruków, publikacji anonimowych lub wydawanych pod pseudonimami, $z$ fałszywymi adresami wydawniczymi;

- zróżnicowana, wielowarstwowa, wielotematyczna struktura formalna i treściowa dawnych księgozbiorów. Odtworzenie struktury i jej prawidłowa interpretacja nastręcza dużych trudności. Jak podkreśla B. Bieńkowska, wy-

${ }^{90}$ Zob. Straty bibliotek $w$ czasie II wojny światowej $w$ granicach Polski z 1945 roku. Wstępny raport o stanie wiedzy, red. nauk. A. Mężyński, cz. 1: Analiza, oprac. B. Bieńkowska, W. Kowalski, H. Łaskarzewska, U. Paszkiewicz, S. Waligórski (i in.), cz. 2: Tablice, oprac. S. Waligórski, cz. 3: Bibliografia, oprac. U. Paszkiewicz, Warszawa 1994; Biblioteki na wschodnich ziemiach II Rzeczypospolitej. Informator, red. nauk. B. Bieńkowska, oprac. U. Paszkiewicz, H. Łaskarzewska, J. Szymański, St. Waligórski, Poznań 1998; Informator o stratach bibliotek $i$ księgozbiorów domowych na terenach Polskich okupowanych w latach 1939-1945 (bez Ziem Wschodnich), red. nauk. B. Bieńkowska, oprac. U. Paszkiewicz, J. Szymański, Poznań 2000.

${ }^{91}$ Zob. np. sprawozdanie Powiatowego Inspektora Szkolnego pow. jędrzejowskiego na temat rabunku księgozbiorów przez ludność i ,instytucje uzbrojone” w trakcie tzw. parcelacji dworów - dokument cytowany przez R. Piasecką, Stan organizacji bibliotek $w$ powiecie jędrzejowskim $w$ latach 19451950, „Kieleckie Studia Bibliologiczne”, 2001, t. 6, s. 63. 
maga to od badacza „bardzo szczegółowej, a równocześnie szerokiej i wielostronnej erudycji”" ${ }^{22}$, a także umiejętnego wykorzystania odpowiednich metod badawczych, przede wszystkim bibliologicznych - bibliograficznej, typograficznej i proweniencyjnej, nauk pomocniczych bibliologii, w tym źródłoznawstwa bibliologicznego, jak również metod filologicznych oraz historycznych; - fragmentaryczność cech nabytych pozostałości, wynikająca np. z usuwania znaków własnościowych. Czasem jest to działalność świadoma, np. usuwanie starych sygnatur i nadawanie nowych ${ }^{93}$, czy usuwanie ekslibrisów, m. in. $z$ książek pochodzących $z$ grabieży (np. w zapasowym magazynie moskiewskiej Biblioteki im. Lenina zajmowano się, według Sigistasa Jegeleviciusa, wywabianiem ekslibrisów, zdrapywaniem podpisów, pieczątek i numerów inwentaryzacyjnych książek, pochodzących m.in. $z$ polskich zbiorów. Tak „oczyszczone” książki przeznaczano na wymianę ${ }^{94}$ ). Czasem zaś następuje w skutek przypadku, np. za przyczyną nieumiejętnych zabiegów konserwatorskich;

- zła czytelność cech nabytych pozostałości (np. nieczytelne znaki własnościowe, zwłaszcza rękopiśmienne, ale także źle odbite, zamazane pieczątki), co uniemożliwia niekiedy ich poprawną interpretację. W takich przypadkach badania proweniencyjne, naturalnie przy wykorzystaniu dorobku sfragistyki i neografii, mogą okazać się bezskuteczne, przede wszystkim $z$ powodu braku materiału porównawczego wtedy, gdy badacz ma do dyspozycji tylko jeden obiekt $z$ dawnej kolekcji.

W świetle powyższych rozważań należy zgodzić się z opinią B. Bieńkowskiej, że na podstawie samych pozostałości nie można odtworzyć „ścisłych relacji między zbiorami a ich twórcami i użytkownikami, ani stopnia ich przeciętności bądź indywidualności. Księgozbiory mogą więc świadczyć o nich tylko w sposób pośredni, wymagający wielu precyzyjnych uściśleń i korekt"95. Poprawne, naukowe odczytanie pozostałości po księgozbiorach oraz ich interpretacja są uwarunkowane wykorzystaniem dostępnych źródeł pisanych. Przede wszystkim wytworzonych przez:

- badaną książnicę. Znaczenie pozostałości należy weryfikować w konfrontacji $z$ biblioteczną dokumentacją zbiorów i innymi źródłami aktowymi. Ten sposób postępowania pozwala na określenie rzeczywistego miejsca i roli badanych pozostałości w księgozbiorze biblioteki;

\footnotetext{
92 B. Bieńkowska, Kilka uwag i propozycji w sprawie badań księgozbiorów historycznych. „Studia o Książce”, 1986, t. 16, s. 7.

${ }^{93}$ Np. A. M. Stogowska stwierdziła, że: „książek $z$ sygnaturami $z$ okresu międzywojennego zachowało się w zbiorach Biblioteki im. Zielińskich mało, gdyż po podjętej inwentaryzacji prowadzonej w latach 1956-1960 usuwano mechanicznie stare sygnatury, książki noszą ślady wytarcia lub wyskrobania sygnatur”. Zob. A. M. Stogowska, Dzieje i funkcje Biblioteki Towarzystwa Naukowego Płockiego (1820-1985), Płock 1994, s. 121.

${ }^{94}$ S. Jegelevicius, Rok 1939 - rabunek archiwów wileńskich, „Przegląd Wschodni”, 1997, z. 2, s. 387.

${ }^{95}$ B. Bieńkowska, Kilka uwag i propozycji..., s. 8.
} 
- instytucje i organizacje nadrzędne wobec bibliotek. Pozostałości po księgozbiorach należy analizować w zestawieniu $z$ takimi źródłami aktowymi jak: nakazy, zalecenia i instrukcje dotyczące gromadzenia, przechowywania, opracowania i udostępniania zbiorów. Duże znaczenie ma również dokumentacja zawierająca informacje na temat: celów działalności owych podmiotów, ich praw majątkowych do księgozbiorów, ich nakładów finansowych i rzeczowych na powiększanie i utrzymanie księgozbiorów oraz środowiska ich działania - w sensie terytorialnym i społecznym (środowisko intelektualne, zawodowe, etniczne, religijne i polityczne).

Różnorodnych informacji, pomocnych w interpretacji znaczenia pozostałości po księgozbiorach, dostarczyć mogą także inne źródła pisane. Ich naukowa użyteczność jest jednak bardziej zróżnicowana od wymienionych powyżej. Są to:

- źródła wytworzone przez instytucje niezależne względem bibliotek, tj. współpracujące $z$ książnicami, bądź zajmujące się badaniami nad bibliotekarstwem i czytelnictwem ${ }^{96}$, lub badające środowisko społeczne, w którym działały biblioteki. W ostatnim przypadku chodzi o źródła odnoszące się pośrednio do książnic, zawierające informacje na temat ich potencjalnych użytkowników, tj.: liczebności ludności na terenie objętym działalnością danej biblioteki; jej składu - np. według wieku, płci, zawodów, wyznania i narodowości; rozmieszczenia terytorialnego mieszkańców; migracji; stopnia scholaryzacji; uczestnictwa w kulturze; aktywności społecznej i politycznej; bezrobocia, a nawet stanu zdrowotnego ${ }^{97}$.

- źródła nieinstytucjonalne: m.in. informacje o zbiorach zawarte w źródłach literackich, przede wszystkim w korespondencji prywatnej, pamiętnikach, wspomnieniach i biografistyce.

Umiejętne, krytyczne, wykorzystanie źródeł pisanych, a także niepisanych (przede wszystkim pozostałości w postaci lokali bibliotecznych i wyposażenia oraz źródeł ikonograficznych) umożliwia wszechstronne, naukowe wykorzystanie pozostałości po księgozbiorach bibliotecznych, jako źródeł do historii bibliotek.

Kolejne grupy źródeł prymarnych do historii książnic stanowią wg R. Krzysa: - Inskrypcje, które R. Krzys charakteryzuje jako połączenie artefaktów z graficznym zapisem tekstu. Autor klasyfikacji stwierdza, że inskrypcje cechuja się dużą wiarygodnością, wymagając przede wszystkim krytyki ich autentyczności, wykluczenia ewentualnego fałszerstwa ${ }^{98}$.

${ }^{96}$ Zob. np. materiały Sekcji Badania Czytelnictwa Warszawskiego Koła Związku Bibliotekarzy Polskich (działała w latach 1930-1937) w: Teki Dokumentacyjne Zakładu Dokumentacji Księgoznawczej BN, teka nr 80.

${ }^{97} \mathrm{O}$ tym, że stan zdrowia czytelników mógł np. ograniczać wykorzystanie zbiorów świadczy „regulamin dla czytelnika” Biblioteki Publicznej m. st. Warszawy, który w pkt. 11 głosił, że: „W razie choroby zakaźnej w domu, czytelnik nie powinien przychodzić do Bibljoteki przez cały czas trwania choroby, a oddając książki powinien uprzedzić, że pochodzą od chorego", zob. ABP. Wzory druków Biblioteki Publicznej m. st. Warszawy, 1928-1940, sygn. A. 279, k. 8.

${ }^{98}$ R. Krzys, Library Historiography..., s. 1627-1628. 
- Dokumentację urzędową, którą R. Krzys uważa za najbardziej wiarygodną wśród wszystkich źródeł do historii bibliotek. Zwraca uwagę na jej wysoką jakość merytoryczną i kompetencje osób, które ją sporządzały. Takie źródła jak dokumentacja prawna, legislacyjna, statuty, umowy, dokumentacja sądowa, dokumentacja organów zarządzających bibliotekami, dokumentacja agend rządowych, musiały być wytworzone w sposób profesjonalny, ze względu na znaczące konsekwencje ewentualnych błędów w dokumentach tego typu. Wiarygodność dokumentów urzędowych wynika zatem $z$ precyzji i autentyczności zawartych w nich informacji. R. Krzys zastrzega jednak, iż nie można zakładać a priori nieomylności dokumentów urzędowych ponieważ, np. $z$ przyczyn politycznych, mogą stronniczo opisywać rzeczywistośćc ${ }^{99}$.

Ostatnia uwaga amerykańskiego badacza ma uniwersalny charakter. Odnosi się także m.in. do dziejów polskich książnic, zwłaszcza w latach wojny, okupacji i po 1945 r., kiedy to władze okupacyjne a później komunistyczne wytwarzały tendencyjne dokumenty odnoszące się do różnych aspektów działalności bibliotecznej. Wydaje się jednak, że R. Krzys nie docenia przypadków, np. w międzywojennej Polsce częstych, rozmijania się rzeczywistości dokumentów urzędowych $z$ realnym funkcjonowaniem bibliotek. Przykładem może być tutaj Biblioteka Publiczna m. st. Warszawy, działająca w ramach statutu zatwierdzonego 29 marca 1928 r. przez Radę Miejską Warszawy. Decyzje dotyczące personelu Biblioteki Publicznej, spraw administracyjno-gospodarczych i finansowych zapadały w Zarządzie Miejskim, ale obowiązywały m.in. również zalecenia organów kolegialnych, w tym Komitetu Zarządzającego, którego inauguracyjne posiedzenie odbyło się 26 czerwca 1928 r. ${ }^{100}$. Światło na rzeczywistą działalność owego Komitetu, i przy okazji na stan dokumentacji Biblioteki, rzuca odpowiedź (z 21 lipca 1938 r.) jej dyrektora Aleksego Bachulskiego (pełnił funkcję od 1937 r. do 1940 r.) na list dyrektora Wydziału Spraw Ogólnych Zarządu Miejskiego w Warszawie w sprawie statutu organizacyjnego Biblioteki Publicznej. Dr A. Bachulski wyjaśniał: „Co się tyczy najważniejszego pod względem formalnym zagadnienia t. j. Komitetu Zarządzającego, to wprawdzie Biblioteka nie posiada kompletnych akt jednak $z$ fragmentów ich widać, że ostatnie posiedzenie Komitetu Zarządzającego odbyło się dn. 2 grudnia 1932 r." ${ }^{101}$. Przytoczony przykład potwierdza konieczność krytycznej analizy dokumentów urzędowych, nie tylko w zakresie prawdziwości opisu rzeczywistości, ale także w zakresie realnego ich wpływu na jej kształtowanie.

\footnotetext{
99 Tamże, s. 1628.

${ }^{100}$ ABP, Komitet Zarządzający Biblioteką Publiczną założony w r. I928 [w Zarządzie Miejskim m. st. Warszawy], sygn. A. 253.

${ }^{101}$ ABP, Akta organizacyjne Biblioteki Publicznej m. st. Warszawy, teczka 2: Statut Biblioteki Publicznej 1906-1938, sygn. A. 276, k. 75.
} 
- Oficjalną dokumentację instytucji pozarządowych, prywatnych. Zdaniem R. Krzysa jej wiarygodność jest duża, porównywalna $z$ dokumentacją urzędową. Autor podkreślił, że źródła tego rodzaju bywają zdekompletowane, ze względu na mniejszą pieczołowitość w ich przechowywaniu ${ }^{102}$.

Także w przypadku tej grupy źródeł - można ją rozpatrywać razem $z$ dokumentacją urzędową grupe źródeł instytucjonalnych - konieczna jest ich wnikliwa krytyka. Warto przy tym dodać, że przy ocenie źródeł tego rodzaju szczególnie pomocne są formy kancelaryjne, o ile obowiazywały w danych instytucjach - rządowych, samorządowych, społecznych i prywatnych. Na przykład badając źródła instytucjonalne wytworzone w II Rzeczypospolitej, należy wziąć pod uwagę, że przepisy ujednolicające biurowość zostały wprowadzone dopiero w 1931 r., uchwałą Rady Ministrów ${ }^{103}$, a $z$ ich przestrzeganiem w urzędach państwowych bywało różnie. O sytuacji w samorządach świadczy m.in. fakt, że Prezydent m. st. Warszawy zlecił sporządzenie „projektu ramowych przepisów kancelaryjnych" dopiero w $1937 \mathrm{r} .{ }^{104}$. Zaś w przypadku instytucji i organizacji społecznych oraz prywatnych, które prowadzily biblioteki, należy mieć na uwadze, że wiele $z$ nich stosowało własne zasady i formy kancelaryjne lub nie stosowało ich w ogóle.

- Prasę. Według R. Krzysa jej wiarygodność jest porównywalna z dokumentacją urzędową, zwłaszcza publikowane na łamach gazet raporty, dokumenty urzędowe, wszystkie te publikacje, które bywają odbierane przez wielu czytelników jako dokumenty quasi-oficjalne. Mimo to, zdaniem R. Krzysa, materiały prasowe winny być poddane szczególnie precyzyjnej krytyce, zwłaszcza informacje źródłowe zawarte w prasie wydawanej w państwach niedemokratycznych. Autor podkreśla przy tym, że prasa ukazująca się w krajach demokratycznych również nie jest wolna od stronniczości i manipulacji - niejednokrotnie trudnych do wykrycia ${ }^{105}$.

O konieczności znacznie głębszej analizy źródeł prasowych pisałem powyżej, omawiając typologię H. H. McMullena.

- Spuścizny prywatne, w tym korespondencja, wspomnienia, dzienniki, pamiętniki, autobiografie. R. Krzys, podkreślił, że źródła tego typu wymagają badania wiarygodności informatora, twórcy źródła, jak też odkrycia rzeczywistych celów jakie chciał osiągnąc w momencie jego tworzenia ${ }^{106}$.

Odnośnie krytyki źródeł prymarnych autor nie uwzględnił w swojej analizie m.in. problematyki jednorodności źródła i jego postaci pierwotnej, czasu i miej-

${ }^{102}$ R. Krzys, Library Historiography..., s. 1628.

${ }^{103}$ Zob. Metodyka pracy archiwalnej, praca zbior., red. S. Nawrocki i S. Sierpowski. Poznań 1992, s. 21.

${ }^{104}$ Zob. Pismo okólne Prezydenta Miasta $z$ dnia 27 września 1937 i załączony projekt „Przepisy kancelaryjne Zarządu Miejskiego” w: ABP, Zarządzenia okólne Zarządu Miejskiego m. st. Warszawy. Teczka 5: Okólniki Prezydenta Miasta 1937, sygn. A. 246, k. 96-117.

${ }^{105}$ R. Krzys, Library Historiography..., s. 1628.

${ }^{106}$ Tamże. 
sca jego powstania. Szczególny nacisk położył natomiast na badanie autentyczności źródeł pisanych - wedle następujących kryteriów:

a) materialnej postaci źródła;

b) autentyczności autorstwa;

c) autentyczności tekstu ${ }^{107}$.

Drugą grupę źródeł wyróżnioną przez R. Krzysa stanowią źródła wtórne, czyli materiały zawierające informacje „Z drugiej ręki” o badanej rzeczywistości. Dlatego ich wiarygodność jest mniejsza od źródeł prymarnych. Historyk powinien zakładać istnienie błędów w źródłach wtórnych i je zidentyfikować. Zdaniem R. Krzysa użyteczność tego rodzaju źródeł dla historyka bibliotek wynika Z konieczności:

1. określenia ogólnego tła historycznego badanych zjawisk;

2. zgromadzenia informacji na temat tych problemów badawczych, w zakresie których wiedza historyka bibliotek jest niewystarczająca;

3. zgromadzenia informacji źródłowych, które w inny sposób nie są dla historyka dostępne;

4. uniknięcia dublowania innych prac badawczych;

5. zidentyfikowania błędów popełnionych przez poprzedników i wyciągnięcia $z$ nich korzyści naukowych ${ }^{108}$.

W innym opracowaniu, poświęconym teorii bibliotekoznawstwa porównawczego, R. Krzys zaliczył do źródeł wtórnych przede wszystkim informacje zawarte w opracowaniach $z$ zakresu bibliotekoznawstwa. Źródła wtórne powinny być według niego poddane krytyce $z$ punktu widzenia ewentualnych luk i sprzeczności w nich zawartych ${ }^{109}$.

Oceniając typologię R. Krzysa należy podkreślić, że stosowany przez amerykańskich historyków bibliotek (także H. McMullena, L. J. Batesa) podział na źródła prymarne i wtórne, nie jest wystarczający. Trudno bowiem niejednokrotnie rozstrzygnąć czy informacje podawane w źródłach pisanych do historii bibliotek mają charakter pierwotny (prymarny) czy wtórny (z drugiej ręki), a przecież w takim ujęciu charakter źródeł decyduje o ich naukowej użyteczności. Są to ważne cechy źródeł, ale równie istotne jest to, czy są to źródła pisane, czy niepisane (nie uwzględnianie tego podziału prowadzi w konsekwencji m.in. do pomijania istotnych grup źródeł do historii bibliotek, np. ikonografii i dokumentacji mechanicznej, jak to ma miejsce w klasyfikacji R. Krzysa), jak również czy są to źródła adresowane, czy nieadresowane (istotny podział $z$ punktu widzenia krytyki źródeł). Osobiście za szczególnie użyteczny dla historii bibliotek pierwszej połowy XX w. uważam podział źródeł z punktu widzenia relacji, jakie zachodzą między wystawcą (twórca) źródła i jego odbiorcą.

\footnotetext{
${ }^{107}$ Tamże.

${ }^{108}$ R. Krzys, Library Historiography, w: Encyclopedia of Library and Information Science, ed. A. Kent, H. Lancour, J. E. Daily, W. Z. Nasri, New York 1975, s. 305-306.

${ }^{109}$ R. Krzys, G. Litton, World Librarianship..., s. 35-36.
} 
Generalnie rzecz biorąc nie tylko w amerykańskiej, ale i w całej, dotychczasowej literaturze bibliologicznej, dotyczącej historiografii bibliotek, brak jest wyczerpującego studium poświęconego problematyce źródłoznawczej. Przyczyn tego stanu rzeczy można upatrywać w niezgodności poszczególnych autorów, co do właściwego przedmiotu badań historyka książnic. Przedmiot badań wpływa zaś na zasób źródeł będący ich podstawą. Część historyków za podstawowy przedmiot badań uznaje dzieje księgozbiorów (np. Andreas Anderhub), inni ujmują bibliotekę jako samoistny fenomen, którego historia ma własny przedmiot i metodologię badań (np. Marianna Mlekicka ${ }^{10}$ ), jeszcze inni (H. J. Vleeschauwer, a także w pewnym stopniu Alistair Black, kwestionujący sens badań skupionych na bibliotekach jako instytucjach, na praktyce działalności bibliotecznej ${ }^{111}$ ), uważają, że książnice pozostają jedynie instytucją pomocniczą w rozpowszechnianiu książki, elementem procesu bibliologicznego. Skrajne postawy godzą autorzy podkreślający zarówno wagę badań nad biblioteką jako instytucją, jak i jej rolą w systemie książki oraz funkcjami: kulturalną, społeczną i polityczną (m.in. H. McMullen, K. Migonn ${ }^{112}$, B. Bieńkowska, Z. Gaca-Dąbrowska i R. Krzys). Postawa badawcza wpływa na refleksję źródłoznawczą historyków bibliotek. Jedni dążą do wyodrębnienia tych grup źródeł, które można uznać za specyficzne dla dziejów książnic (np. A. Anderhub ${ }^{113}$ ), czasem zaliczając do nich źródła, które specyficzne nie są (np. Hans-Joachim Koppitz ${ }^{14}$ ), inni, niesłusznie moim zdaniem, zaprzeczają istnieniu takich źródeł (H. J. Vleeschauwer).

Jak do tej pory jednak żaden $z$ historyków bibliotek nie podjął się całościowego ujęcia problematyki źródeł do dziejów książnic, uwzględniającego zarazem ich uniwersalne cechy jak i te, które wynikają ze specyfiki zachowanego zasobu

\footnotetext{
${ }^{110}$ M. Mlekicka: Wykorzystanie źródet drukowanych z lat 1795-1918 do badań nad dziejami ksiązki polskiej. Zarys metodologiczny, „Z Badań nad Polskimi Księgozbiorami Historycznymi”. Warszawa, 1977, z. 3, s. 23-56.

${ }^{111}$ A. Black, New Methodologies in Library History: A Manifesto for the „New” Library History, „Library History”, 1996, 11, s. 76-85; A. Black, New Times for Library History, „Librarians World” 1998 nr 7 s. 45-46; A. Black, A Response to „,Whither Library History? ”, „Library History”, 2001, 17, s. 37-39. Polemikę z tezami A. Blacka podjęli D. G. Davis Jr., J. A. Aho, Whither Library History? A Critical Essay on Black's Model for the Future of Library History, with Some Additional Options, „Library History” 2001, 17 s. 21-37.

${ }^{112}$ M.in. autor ważnego, inspirującego artykułu Problematyka źródłoznawcza w bibliologii („Studia o Książce”, 1985, t. 15, s. 3-18). K. Migoń przedstawił w nim swoją klasyfikację źródeł użytecznych w odtwarzaniu historycznego procesu bibliologicznego. Odnosi się ona jednak do całości zasobu źródeł bibliologicznych, a nie tylko do dziejów książnic.

${ }^{113}$ A. Anderhub, Grundzüge einer Quellenkunde zur Bibliotheksgeschichte, w: Bibliotheksgeschichte als wissenschaftliche Disziplin: Beiträge zur Theorie und Praxis. Referate des siebten Fortbildungsseminars für Bibliothekare vom 23. bis 25. Januar 1979 in der Herzog August Bibliothek Wolfenbüttel, hrsg. von P. Vodosek, Hamburg 1980, s. 142-156.

114 H-J. Koppitz, Bemerkungen zum Fachbibliotheksgeschichte in der Bibliothekarausbildung, w: Bibliotheksarbeit heute. Festschrift für Werner Krieg zum 65 Geburtstag am 13 Juni 1973, Frankfurt an Main 1973, s. 21-31.
} 
źródłowego, powstałego w określonych warunkach, miejscu i czasie ${ }^{115}$. Być może dlatego, że historycy bibliotek przyjmują, iż metodologia pracy ze źródłami historycznymi jest ogólnie znana, czemu jednak przeczy często spotykana w wielu artykułach krytyka metodologicznej poprawności opracowań $z$ zakresu dziejów książnic. Ze względu na skomplikowanie i rozległość tematyki rezultatem wyczerpującej analizy źródłoznawczej materiałów do dziejów bibliotek byłaby publikacja nie mająca granic - stwierdził, nieco przesadnie, amerykański historyk Sidney Ditzion ${ }^{116}$. Warto jednak podjąć takie zadanie, chociażby w odniesieniu do określonego zasobu źródłowego - dlatego osobną rozprawę poświęciłem źródłom do dziejów książnic w Polsce w latach 1918-1947. Niniejszy artykuł stanowi nawiązanie do fragmentów tej rozprawy ${ }^{117}$.

115 O tym jak istotną rolę odgrywają przy ocenie źródeł okoliczności ich powstania można się przekonać analizując źródła do dziejów polskich bibliotek wytworzone w okresie II wojny światowej i po jej zakończeniu. Zob. m.in.: Biblioteki naukowe w Generalnym Gubernatorstwie w latach 1939-1945. Wybór dokumentów źródłowych, wybór i oprac. A. Mężyński, przy współpr. H. Łaskarzewskiej, Warszawa 2003; B. Bieńkowska, Potyczki ze źródłami bibliologicznymi (na przykładzie urzędowej dokumentacji strat bibliotek $w$ Polsce podczas II wojny światowej), „Roczniki Biblioteczne” 2001 s. 3-28; J. Plis, Źródła dotyczace strat bibliotek w czasie II wojny światowej. Ocena ich wiarygodności, w: Symposia bibliologica. Dokumentacja księgozbiorów historycznych; wspótpraca krajowa i międzynarodowa. Skutki II wojny śwsiatowej dla bibliotek polskich, red. nauk. A. Mężyński, Warszawa 1995, s. 139-149.

116 S. Ditzion, The Research and Writing of Library History, w: Towards a Theory of Librarianship. Papers in Honour of Jesse Hauk Shera, ed. by C. H. Rawski, Metuchen, New Jersey 1973, s. 63.

${ }^{117}$ J. Puchalski, Źródła do historii bibliotek $w$ Polsce w latach 1918-1947. Studium bibliologiczne. Maszynopis złożony do druku we wrześniu 2006 r. w Wydawnictwie Stowarzyszenia Bibliotekarzy Polskich. 